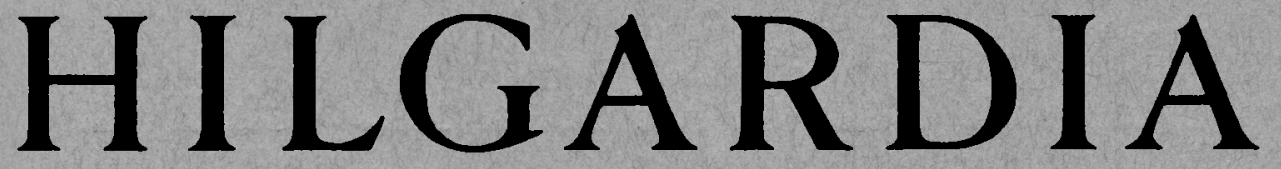

A Journal of Agricultural Science Published by the California Agricultural Experiment Station

\title{
PHYLLOXERA-RESISTANT \\ GRAPE ROOTSTOCKS FOR THE \\ COASTAL VALLEYS OF CALIFORNIA
}

LLOYD A. LIDER

UNIVERSITY OF CALIFORNIA · BERKELEY, CALIFORNIA 
The grape phylloxera-Phylloxera vitifoliae (Fitch) - was introduced into California prior to the year 1860 . Since its introduction it has been a destructive pest in California vineyards.

Various control methods for this harmful aphid have been tried. One of these is the breeding and selection of phylloxera-resistant grape rootstocks. This paper reports on a series of trials of rootstocks selected over the past 50 years by workers in the U.S. Department of Agriculture and the Department of Viticulture of the College of Agriculture. These trials are being conducted in commercial vineyards at various locations and under a wide range of environmental conditions throughout the coastal valleys of California.

A statistical survey of the data collected has shown that the most popular rootstock used commercially, Rupestris St. George is not the most suited under the conditions tested, and that the experimental stock Aramon x Rupestris Ganzin \#1 is generally the most vigorous and productive of the stocks under consideration. 


\section{$\begin{array}{lllllllll}H & \text { I } & \text { L } & G & \text { A } & \text { R } & \text { D I } & \text { A }\end{array}$}

A Journal of Agricultural Science Published by

the California Agricultural Experiment Station

\section{PHYLLOXERA-RESISTANT GRAPE ROOTSTOCKS FOR THE COASTAL VALLEYS OF CALIFORNIA ${ }^{1}$}

\section{LLOYD A. LIDER ${ }^{2}$}

For nearly a hundred years the inherent characteristics of the native wild American species of grapes, their adaptability to soil, climate, and other environmental conditions, as well as their ability to form successful unions with Vitis vinifera fruiting varieties, have been the subject of intensive investigation throughout the grape-growing areas of the world. Of these investigations, the breeding, selection, and testing of grape rootstocks for phylloxera resistance comprise one of the most widely explored fields of study in modern viticultural research.

\section{HISTORY OF PHYLLOXERA INFESTATIONS}

Because of its destruction of grapevines the world over, the grape phylloxera, Phylloxera vitifoliae (Fitch), ${ }^{3}$ is the most widely known of the aphid insects. This insect is indigenous to North America, its native habitat being confined to the area east of the Rocky Mountains. It is found in great abundance on the native wild species of grapes in the Mississippi Valley, in the southeastern portion of the United States, and westward through the state of Texas, New Mexico, and into Arizona. Asa Fitch (1854), entomologist in the New York State Agricultural Society, first reported the leaf galls produced by this insect on native wild American grapes and first described the species. Shimer (1867) detected two different forms of the insect-the winged migrant and the wingless gall forms-and described their relationship. In the summer of 1868, Planchon, Bazille, and Sahut (1868) found the insect on weakened $V$. vinifera vines near Saint-Remy, France. These authors reported that at that time the insect could be found in hundreds of locations in central and southern France. They indicated that it had been carried to France and had multiplied on the susceptible grapevines several years prior to the discovery of its presence.

${ }^{1}$ Submitted for publication February 28, 1957.

${ }^{2}$ Assistant Professor of Viticulture and Assistant Viticulturist in the Experiment Station, Davis.

${ }^{3}$ The scientific names Dactylasphaera vitifoliae (Shimer) and Phylloxera vastatrix [(Planchon) Signoret] may also be found in the literature.

"See "Literature Cited" for citations referred to in the text by author and date. 
Davidson and Nougaret (1921) stated that the grape phylloxera, though not native to California, was introduced into the state soon after its presence in France had been established, with the first evidence of phylloxera infestation in California dating as far back as 1858. It was not until 1873, however, that the presence of the insect was definitely established on dying vines near the city of Sonoma and in the Napa Valley by Appleton (1880). Just as in France, the early introduction and spread of phylloxera was unsuspected; the insect thus became widely established over many vineyard areas of the state before its presence was recognized.

Presumably, phylloxera was introduced into California on nursery stock either from the eastern part of the United States or from Europe and possibly from both sources, for during the middle of the nineteenth century large numbers of imports of vineyard planting stock were coming into California from both of these parts of the world.

By the time the impact of phylloxera in the vineyards of California was felt and the tragic situation which had developed in Europe was brought to attention, the pest was widespread over the state. Undoubtedly the insect found its way into all of the large grape-growing districts of the state. Whether or not it became permanently established on the vines of these districts depended to a great extent upon the environmental conditions. Nougaret and Lapham (1928) have shown that certain types of soils in California, such as the light-textured or sandy soils of the state's interior valleys and desert regions, possess attributes which restrict or inhibit the propagation of phylloxera. Principally for this reason, large grape-growing areas have remained relatively free from phylloxera infestation over the past 100 years.

\section{CHARACTERISTICS OF PHYLLOXERA}

The phylloxera in California is practically limited to its underground parthenogenetically reproduced forms. According to Davidson and Nougaret (1921) its normal life cycle in the state is wholly parthenogenetic and the natural diffusion of the insect is due to the wandering of the young radicicole larvae.

In contrast, the life cycle of phylloxera is quite complicated in its native Mississippi Valley habitat, and in the humid viticultural regions of the world. In addition to the parthenogenetic root-inhabiting form, it includes several sexual stages. From midsummer to fall a varying percentage of the larvae on the roots become nymphs and these later emerge from the ground as winged insects capable of flying or being transported by the wind to other vines. The eggs of these winged migrants hatch into the male and female representatives of the species. The eggs laid by the females of this sexual generation hatch in the spring into a stem mother or fundatrix which settles on the upper surface of a young leaf of the grapevine. The insects hatching from the eggs produced by the stem mother inhabit galls produced on the leaves. Some of the young larvae of the leaf-gall generation, however, desert the leaves and migrate to the roots of the grapevine to become the rootinhabiting form, thus completing the cycle. 
Since the winged females and the subsequent gall form do not function in California, the natural movement of phylloxera is limited to that of the newly hatched radicicole crawling on the surface of the soil or through subterranean passages or cracks. Hilgard (1884) was one of the first to suspect this peculiarity in the life cycle and made suggestions for further investigation of this phenomenon.

Davidson and Nougaret (1921) have pointed out that the production and relative abundance of migrants formed in a population of root-inhabiting larvae are markedly influenced by the character of the soil, the condition of the plant's roots, and the humidity and temperature of the area concerned. Hot, dry areas with sandy soils are the least favorable for the wanderers or migrants. It is easy to understand, therefore, with the very diverse climatic conditions and soil types found in the viticultural areas of California, that at least some of these areas would remain free of phylloxera. Experience has proved this to be the case in several large districts in the San Joaquin Valley.

Many agencies, however, further the spread of phylloxera once it has become established in a district. Among these are vehicles, cultivation implements, picking boxes, vine supports, flood and irrigation water, and vineyard planting stock-both rooted vines and cuttings. Controlling the spread of the insect on vineyard planting stock is therefore extremely difficult. Possibly through rigid quarantine measures a few of the more isolated districts of the state, partially protected by natural climatic conditions or by the fact that they have been developed in more recent years, could be maintained free of phylloxera, but, in general, the time is past for quarantine to be effective in many areas of the state. This situation is especially true in the older viticultural areas of the state which were being established during the second half of the nineteenth century. The biology of the grape phylloxera was not then thoroughly understood. Quarantine measures were not in effect and many new plantings of vines were being established. Vineyard planting stock was being imported from Europe in huge quantities and indiscriminately spread over the areas of the state suitable at that time for vineyard plantings.

\section{NEED FOR PHYLLOXERA-RESISTANT ROOTSTOCKS}

Since the opportunity is past to afford protection through quarantine in the older grape-growing districts of California, the only possibility left open to growers in these areas is to institute means of surviving with the phylloxera infestation. This idea has resulted in the widespread use of phylloxeraresistant grape rootstocks as vineyard planting stock in these districts. This is especially true of plantings in the central coastal counties of California.

With the identification of phylloxera in the declining vineyards of the coastal valleys in the early 1870 's, the growers of the state undertook the control measures that were being tried in France at that time. Most of these procedures were concerned with eradication of the insect by means such as fumigation of the soil with carbon bisulfide, sanding of the root zone of infected vines, or complete submersion of the vineyard with several inches 
of water during the dormant period in an effort to suffocate the insects. Eradication was soon found to be impracticable, however, and interest in the use of resistant rootstocks developed rapidly.

Having fresh in mind the picture of the terrific destruction that was being wrought in the vineyards of Europe at that time( hundreds of thousands of acres of vines were dying in France alone), the growers turned towards phylloxera-resistant American vines for planting stock.

It was Laliman (1869) who pointed the way toward the possibility of using the resistance to be found in the American species of Vitis. Soon after his discovery of phylloxera resistance, Bazille (1871) succeeded in making successful grafts of vinifera varieties on American stocks and investigations of phylloxera-resistant rootstock were begun.

Between the years 1885 and 1900 a tremendous effort was put forth by French and other European research workers to investigate the resistance and suitability in the vineyard of American species of Vitis and their hybrids. Work published during this period by Viala (1889), Ravez (1895), Viala and Ravez (1896), Millardet (1885), Sahut (1885), Mazade (1894), Couderc (1888), and others led the way for the reconstruction of the phylloxerated vineyards of the world.

\section{EARLY ROOTSTOCK TRIALS}

The Board of State Viticultural Commissioners, created by an Act of the California Legislature in 1880, was instrumental in gathering and publicizing information on the status of research against phylloxera during this crucial period (Anonymous, 1881). In the second annual report of this commission, both Krug (1882) and Haraszthy (1882) gave statistics on the widespread propagation of vines presumed to be resistant to phylloxera and commented on the continued increase in new plantings in infested areas of the state in the face of the destruction which phylloxera was bringing about at that time.

At first the plantings on American vines were largely done without selection of planting stock or regard to whether or not the soil was infested or clean. The names Wild Riparias, Aestivalis, Mustang, Rupestris, Californicas, and Arizonicas appear among the lists of seedlings being used. Because of the lack of resistance many of these stocks failed outright. Others were inherently weak, or lacked adaptability to the environmental conditions found in California and thus failed. A few, however, did survive. During this period the species Vitis californica, found growing wild in the coastal valleys of California, was one of the types collected and planted widely. Claims were put forth that it was adequately resistant and by the mid1880's several hundred thousand vines of this species had been planted and grafted. It was later proved to be worthless in infested soil. The first authenticated report of susceptibility of $V$. californica was made by Krug, Crabb, and Wheeler (1887) who found phylloxera active on wild vines of the species near the town of Napa, in Napa County.

During this early period, while there was confusion in the young California industry, the French research workers had initiated an intensive program of investigation. With a vigorous program involving selection as 
well as a good deal of trial and error, they were beginning to produce promising rootstock types. Millardet (1885) described useful varieties of $V$. rupestris and $V$.riparia which were soon to become the new foundation upon which the viticultural industry of the world was reestablished. From these early promising selections of the French the following were introduced to California: Rupestris St. George (Rupestris du Lot), Rupestris Martin, Rupestris Ganzin, Riparia Gloire, and Riparia Grande Glabre.

In 1894 the State Viticultural Commission was abolished and the responsibility for investigations of problems confronting the industry was placed in the hands of the Agricultural Experiment Station of the University of California. During the next few years, the College of Agriculture's activities in the field of viticultural research on grape rootstock were confined to offerings of advice on the relative merits of stocks being used at the time and to gathering and distributing propagating wood of the most promising types available. Hayne (1896) pointed to the fact that growers of the state should not continue to gather indiscriminately the numerous seedling selections of the species $V$. riparia and $V$. rupestris which were in use in California at that time. He pointed out the promise of one selection in the nursery, as well as in the bearing vineyard, and recommended that it, the Rupestris Saint George, be planted in the phylloxerated areas of California. During this period many forms of Rupestris had appeared and were experimented with. In Hayne's discussion $(1896$, p. 28) of the usefulness of the many varieties of Vitis rupestris he says "among these some are found that, though they do not possess as much absolute resistance as others, yet, on account of their easy adaptability, they are in many eases as highly esteemed as those which have a higher resisting power. It is for this reason that in selecting from the one hundred and fifty or more varieties of Rupestris to introduce into California, the University selected the Rupestris St. George ...."

A great fund of information was contributed during this early period from diverse sources concerning the choice of and techniques for the use of rootstocks. Much of this information and advice was soundly based and the industry was advanced. Frequently, however, even though the advice was sincere it led up false trails. With an ever-increasing demand for grapes and grape products from California vineyards, new plantings were undertaken and the industry continued to expand in the phylloxerated areas. This resulted from the efforts of interested growers who were guided by the results of the research of the early workers on viticultural problems in California.

Because of its vigor, ease of grafting, and ability to root readily from cuttings in the nursery the one rootstock variety Rupestris St. George gained favor with growers over the state and became established as the most promising phylloxera-resistant rootstock variety.

In 1903 the United States Department of Agriculture began the establishment of experimental vineyards in several of the grape-growing districts of California (Husmann, 1910). The general object of these plantings was to grow as many vinifera rootstock combinations as possible in locations representative of the more important grape-growing areas of the state. Husmann, Snyder, and Husmann (1939) reported the completed studies in these experimental vineyards. Figures were given on longevity of various graft 
combinations, the influence of vigor in the stock on the scion variety, and the influence of the stock on such phenomena as date of maturity, blooming date, and date of first growth in the spring. These authors listed, in summary, the more vigorous rootstocks which showed the widest adaptability and higher resistance to phylloxera. Included in this listing were the stocks which tended to impart the greater vigor to the scion varieties which were tested. The varieties of rootstocks mentioned included the following: Rupestris St. George, Mourvèdre $\times$ Rupestris 1202, Solonis $\times$ Othello 1613, Dogridge, and Aramon $\times$ Rupestris Ganzin \#1.

In 1911 the University of California initiated two extensive rootstock experiments, one located on the Davis Campus and the other near Kearney in Fresno County. According to Bioletti, Flossfeder, and Way (1921), it was the aim of these experiments to test the suitability of a limited number of rootstocks, chosen from the wide array available at that time, for the commercial varieties of grapes being grown in the state. They presented comparative data on the ability to root, ease of grafting, vigor and durability in the vineyard, and the crops produced of 21 stocks grafted to many of the common fruiting varieties. From these data seven principal stocks were chosen for further consideration with three being pointed out as the most recommended for common varieties of grapes in the phylloxerated vineyards of California. These were Chasselas $\times$ Berlandieri 41-B, Riparia $\times$ Rupestris 3306 , and Riparia $\times$ Rupestris 3309. For unexplained reasons these trials were discontinued in 1919 after only eight years of records were gathered. Therefore, the very important aspects of longevity of the combinations tested and the performance of the stocks after the vines reached full maturity were not determined. It is interesting to note, however, that the rootstock variety Rupestris St. George was consistently shown as a poor performer in these experiments. The authors did not offer a suggestion as to why.

\section{RECENT RESEARCH}

On the basis of previous investigations and experience, the late Professor H. E. Jacob ${ }^{5}$ chose a limited number of phylloxera-resistant stocks which appeared most likely to do well in California vineyards. The earlier work carried out by the United States Department of Agriculture and the Department of Viticulture at Davis and Kearney had shown a need for more widespread testing of these more favorable stocks. Professor Jacob also realized that it was necessary to extend the test plot work into as wide a range of environmental conditions as possible. The wide variation of soil and climatic conditions in California's grape-growing regions, he concluded, made it impossible to extend the results from a few centrally located trials to all the vineyards of the entire state.

In 1929 Professor Jacob inaugurated the cooperative research which has become an important part of the Viticulture Department's activities. Using the experience of past research and choosing from the large number of stocks available it was his thought to place in growers' vineyards a few well-chosen

${ }^{5}$ Harry E. Jacob, Associate Professor of Viticulture and Associate Viticulturist in the Experiment Station, initiated the present phase of research on grape rootstocks and contributed materially to its progress until his untimely death in 1949 . 
rootstock trials spread widely over the phylloxerated districts of the state. Thus, he would be able to measure the effect of the wide range of environmental conditions under which grapes are grown in the state, using commonly grown scion varieties under actual commercial vineyard conditions.

The rootstocks chosen for the experimental trials are shown in the following list.

1. Rupestris St. George

2. Riparia Gloire de Montpellier

3. Dogridge ( $V$. champini)

4. Berlandieri $\times$ Rupestris $99-\mathrm{R}$

5. Berlandieri $\times$ Rupestris $110-R$

6. Berlandieri $\times$ Rupestris 57-R

7. Berlandieri $\times$ Rupestris 44- $\mathrm{R}$

8. Riparia $\times$ Rupestris 3306

9. Riparia $\times$ Rupestris 3309
10. Berlandieri $\times$ Riparia 420-A

11. Berlandieri $\times$ Riparia 5-A

12. Solonis $\times$ Othello 1613

13. Solonis $\times$ Riparia 1616

14. Mourvèdre $\times$ Rupestris 1202

15. Aramon $\times$ Rupestris Ganzin No. 1

16. Chasselas $\times$ Berlandieri $41-\mathrm{B}$

17. Bourrisquou $\times$ Rupestris 93-5

18. Rupestris $\times$ (Vinifera ?) $\mathrm{XX}$

Of the rootstocks listed, the first three are pure American Vitis species selections, the next ten are hybrids between two American species (one or both of which are phylloxera resistant), and the last five are hybrids between $V$. vinifera and one or more phylloxera-resistant American species.

In general, the pure American species selections and the Americo-American hybrid rootstocks (first and second groups mentioned above) root with more difficulty but are higher in phylloxera resistance than those in the third group. Not all of these stocks occur in each of the trials currently being considered; and the same stocks are not consistently repeated in all the trials. Since the various individual parts of the experiment were established over a period of several years and the environmental conditions under which they were established are extremely variable, the choice of stocks for each individual trial was influenced by a number of factors-the soil type, scion variety to be used, space allotted for the trial, desires of the cooperating grower, and other conditions.

An individual trial in this work consists of one scion variety grown upon a number of rootstock varieties. Most trials consist of from 15 to 40 vines on one row each of 5 to 10 rootstock varieties. To serve as a standard for comparison, one lot of vines on the rootstock Rupestris St. George was included in every trial. This was logical since this stock is currently used in the wine-grape plantings in the coastal valleys of California to the exclusion of practically all other phylloxera-resistant rootstocks.

Figure 1 is an outline map of the coastal areas of California where grapes are grown. Each dot on this map indicates the approximate location of one of the experimental trials in a commercial growers' vineyard. The city of Ukiah in Mendocino County marks the approximate northern limit of the grape area in the coastal valleys. Trials have been placed in various vineyards of interested growers south from this point, through the Napa Valley and then generally in the Livermore and Santa Clara Valleys lying east and south of the San Francisco Bay.

Vineyard plantings in this area cover a wide range of soil types-from deep fertile loamy soils of the valley floors to the shallower, more rocky, soils of the hillsides. Available moisture is usually confined to the amount stored in the soil from the winter rains. The climate is generally cool, but on 


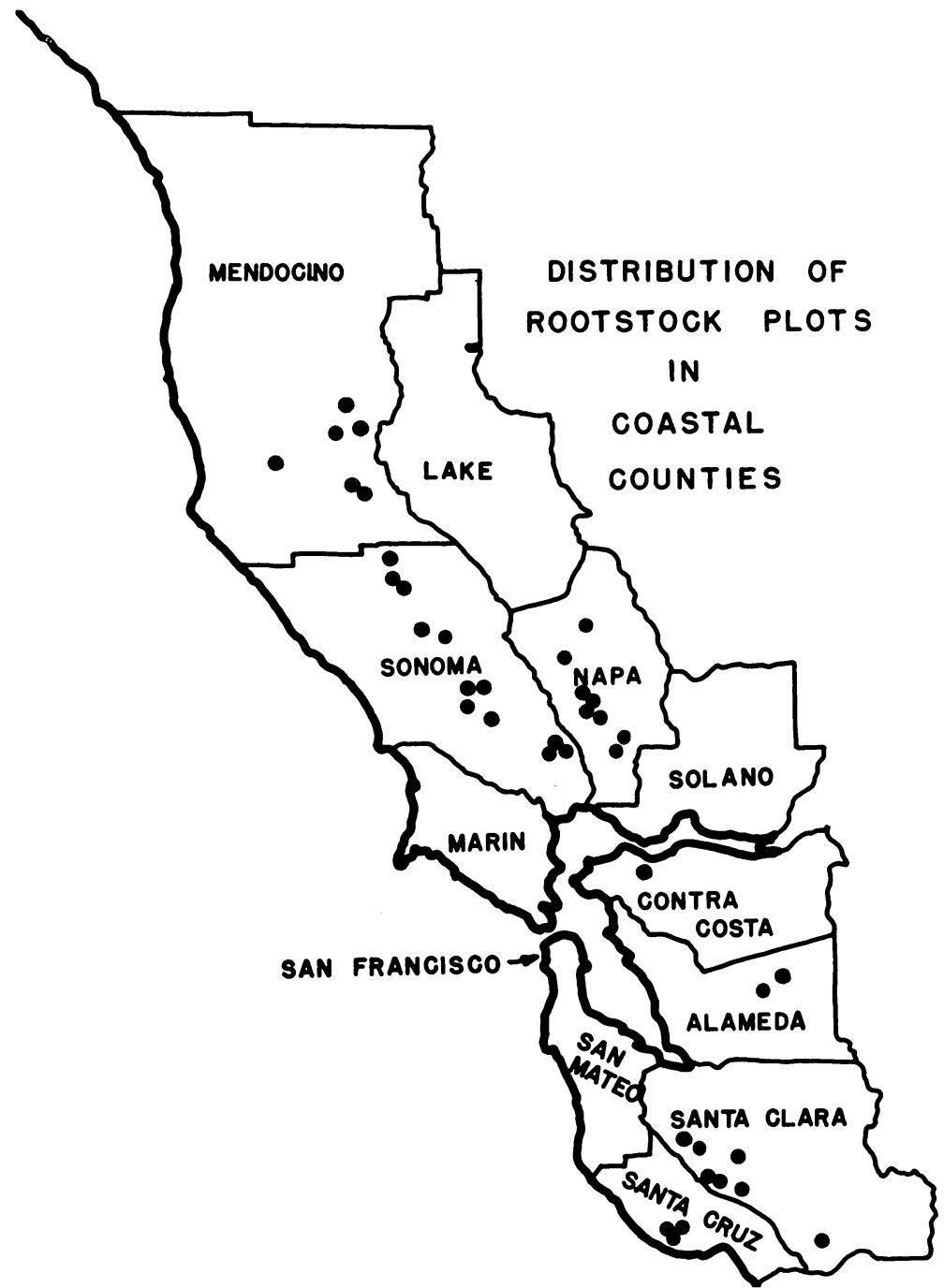

Fig. 1

exposed slopes in the upper parts of the valleys the summer temperatures are moderately warm. Phylloxera infestation is general throughout the area. Although older plantings are occasionally found existing on their own roots, practically all plantings established in the last 50 years in these valleys have been upon phylloxera-resistant rootstocks.

Because of the scattered location of the experimental trials throughout this region they are subjected to a rather wide range of vineyard conditions which are representative of the conditions found in the commercial vineyards of the district. The first of the trials which are considered in this report were established in 1935; additional plantings were made during the 
following eight years. Since the plantings were placed in commercial vineyards there was a degree of unavoidable and variable mortality of the young vines. Where this led to non-uniformity in the initial stand, mixed varieties, or to loss of active interest of the cooperating grower some of the trials were abandoned. Seventeen were carried through to maturity and this report deals with the data accumulated for 10 bearing years for the vines occurring in these trials. Figure 2 illustrates the pattern of one typical experimental planting in a grower's vineyard in Mendocino County. There are 9 rootstocks represented, having 20 vines of each grafted to the scion variety Sauvignon vert. The trial was established in 1941 and since that date a few missing vines have occurred and a number of replants have been established. These replanted vines are excluded from the detailed records.

\section{STUDY RECORDS}

The initial records taken on the planting show stand and condition of the young vines, date of planting, date of grafting or budding, and the location of replants. After the vines came into bearing, a record of the annual increase in size due to growth was obtained by making trunk circumference measurements during the dormant season. The measurement was made at the first or second internode above the graft union. Through the growers' cooperation, annual yield records were obtained for each of the trials by box counts at the time of harvest. Occasionally, when this was impossible, they were obtained by careful estimates-based on cluster counts and weightsmade of the crop per individual vine just prior to harvest. Finally a sample of fruit, usually one or two clusters per vine, was taken from each of the rows on the various rootstocks for measurements of fruit quality. These measurements included the average cluster weight, average berry weights, the percentage of seedless berries, estimates of color, and the total soluble solids and acid content of the extracted juice. The total soluble solids was determined by use of a Balling hydrometer and the total acid content by titration of a juice sample against a standardized solution of sodium hydroxide to a phenolphthalein end point. The quality of color estimations followed the procedure established by the Shipping Point Inspection Service of the California State Department of Agriculture (Anonymous, 1949). Occasionally with some lots, colored and uncolored berries were segregated, counted, and weighed. The color shades were established as "E" for a fully colored purplish-black berry and as " $\mathrm{D}$ " for a reddish-brown to reddish-black berry.

An annual summary of the performance of the scion variety on each of the rootstocks in each of the trials was prepared from the above measurements. As the vines reached maturity, 5- and 10-year summaries of the performance of the stocks were prepared using the annual records. Small differences in the annual performance of the vines in any one of the trials might or might not be significant. It is commonly understood that soil conditions, irrigation, pruning, thinning, disease and insect attack, and the like may, and in many instances do, cause variation in even small plots of vines. However, when records have been accumulated on a trial over a 10-year period and compared with a number of similar trials scattered over a wide range of 


\begin{tabular}{lccccccccc} 
Row & 1 & 2 & 3 & 4 & 5 & 6 & 7 & 8 & 9 \\
\hline Stock & $99-\mathrm{R}$ & 3306 & $5-\mathrm{A}$ & $93-5$ & 3309 & A x R \# 1 & 1202 & St. Geo. & XX
\end{tabular}

\begin{tabular}{|c|c|c|c|c|c|c|c|c|c|}
\hline Vine: 1 & + & + & 0 & 0 & 0 & + & + & + & + \\
\hline 2 & + & + & + & + & + & + & + & + & + \\
\hline 3 & + & + & + & + & + & + & + & + & 0 \\
\hline 4 & + & + & 0 & + & + & + & + & + & + \\
\hline 5 & + & + & + & + & + & + & + & + & + \\
\hline 6 & + & + & + & + & + & $x$ & + & + & + \\
\hline 7 & + & + & + & + & + & + & + & + & + \\
\hline 8 & + & + & + & + & + & + & + & + & + \\
\hline 9 & + & + & + & + & + & + & + & + & + \\
\hline 10 & + & + & + & 0 & ० & + & + & + & + \\
\hline 17 & + & + & + & + & + & + & + & + & 0 \\
\hline 12 & + & + & + & + & + & + & + & + & + \\
\hline 13 & + & + & 0 & + & + & + & + & + & + \\
\hline 14 & + & + & + & + & 0 & + & 0 & + & + \\
\hline 15 & + & 0 & + & + & + & + & + & + & + \\
\hline 16 & + & + & + & + & + & + & 0 & + & + \\
\hline 17 & + & + & + & + & + & + & + & + & + \\
\hline 18 & + & 0 & + & + & + & + & + & + & + \\
\hline 19 & + & + & + & + & + & + & + & + & + \\
\hline 20 & + & + & + & + & + & + & + & + & + \\
\hline
\end{tabular}

Fig. 2. Vineyard layout of a typical grape rootstock trial on the fruiting variety Sauvignon vert in Mendocino County (1941), showing the row arrangement for various stocks. Symbols indicate the following conditions: +-normal, healthy vine; o-replant; $\mathrm{x}$-missing vine. 
soil and environmental conditions, small but continued differences are much more likely to be significant in interpreting the relative merits of two or more rootstock varieties. It is obvious that over a number of years the variability in individual vine performance in a plot of vines brought about by errors in pruning, thinning, irrigation, or disease or insect attack will eventually be cancelled out.

Tables 1 through 17 (at the end of this report) give the averages of annual records taken on the 17 vineyard trials under consideration, with the exception of the trunk circumference measurement. Data for this are represented by a terminal measurement made by averaging three years of records, that is, of the ninth, tenth, and eleventh years. This affords a better idea of the ultimate size attained by the vines on the various stocks than would be shown by averaging all ten of the measurements taken. The figures for the average number of clusters per vine were calculated from the average cluster weight taken from the fruit sample and the crop per vine obtained at harvest. The remainder of the records are averages obtained directly from the annual record of weights or measurements of the individual trials. The county in which the trial is located is shown as well as the scion variety used and the year of planting.

Samples of fruit were gathered from all of these trials, through necessity, at one date each year. The fruit from those in the cooler districts and with later ripening varieties was not as mature as that in other trials at the time of harvest. This has resulted in low Balling readings on all of the stocks in some of the trials, see tables $2,5,7,8$, and 15 .

A general survey of the data presented in these 17 tables shows that only small differences have occurred in the quality of fruit produced on the different rootstocks within any individual trial. Although varying to some degree, berry size, color, and total soluble solids and total acid contents have been found to be equally good or at least commercially satisfactory on practically all the stocks in all the locations at which the trials were placed. On the other hand, a study of these tables will show, first, a marked difference among the scion varieties tested and, second, a marked influence of the environmental conditions upon the total growth produced and the yield of the scion varieties in the different locations.

These summaries indicate a small but consistent difference among the stocks in cluster size for the scion varieties. This difference, however, appears to be closely correlated with the total fruit yields produced on the different stocks, that is, the heavier yielding stocks tend to produce the heavier clusters. This difference will thus be taken up under a consideration of the average yield per vine on the various stocks.

The principal differences, therefore, in the performance of the various rootstocks has been one of vigor of the scion variety as represented by the trunk circumference measurement and a measurable difference in the average yield per vine.

A simple statistical summary of portions of the data from these tables can be used to illustrate these points. In table 18 the figures for the average yield of fruit per vine of the three best performing experimental rootstocks in nine of the trials are compared with Rupestris St. George. These nine 
trials were chosen for this table because the four stocks in question are represented in each trial. The analysis of variance of these data, using each trial as a replicate, shows that the poorest performing stock in yield of fruit per vine is the common commercially used rootstock Rupestris St. George. Further, the stocks $\mathrm{A} \times \mathrm{R} \# 1^{\circ}$ and 1202, both outproduced St. George at odds greater than 99 to 1 .

Table 19 shows a statistical summary of the average trunk circumference for the same rootstocks in the same location as above. St. George also made the smallest total trunk growth of the four stocks considered, growth for the stock $\mathrm{A} \times \mathrm{R} \# 1$ being significantly greater at odds above 99 to 1 .

Data for the two tables mentioned above were gathered from nine trials ranging from Mendocino County to the lower end of the Santa Clara Valley. Seven scion varieties were represented in these plots on a wide diversity of soil types. Four are in valley floor vineyards and five are in hillside vineyards. None were under irrigation. The variation between the trials introduced by these divergent environmental conditions has caused great differences in the data obtained from any one of the stocks at the different locations. In spite of this variation, however, a significant difference is still evident between the rootstocks tested.

Further analyses of the data in the periods of record are shown in table 20. One variety, Zinfandel, was used as the scion variety in four of the trials. Again the stocks A $\times$ R \#1 and 1202 have produced fruit yields greater than St. George significant at odds of 99 to 1.

With the elimination of variation introduced by different scion varieties, the four stocks under question here have maintained about the same relative order of production in the four trials ; however, due to different growing conditions in the four locations a considerable difference in yield exists from one trial to the next. From this table then we might conclude that the stocks $A \times R \# 1$ and 1202 have a wide range of adaptability with the variety Zinfandel. The heaviest bearing vines in each of these four trials has been on one or the other of these two stocks. On the other hand, the stock St. George has been a consistently low producer in these vineyards.

Table 21 examines a portion of the data in the summaries from another point of view. At one of the vineyards used for conducting the cooperative trials three different scion varieties were used in three adjacent commercial vineyard blocks. Having thus removed a large portion of the variation introduced by varying vineyard conditions, one can examine the possible influence of different scion varieties on the stocks at one location. The differences between the five rootstocks which were planted in all three of these trials is not as great as found generally in the seventeen trials studied; however, the same general trend between rootstocks exists. $\mathrm{A} \times \mathrm{R} \# 1$ over the three trials is outproducing St. George to an extent significant at only the 19 to 1 level, with St. George producing about the same quantity of fruit as the other three stocks shown. The three varieties chosen have shown no real difference in the total amount of fruit produced, nor have the stocks listed behaved differently from one variety to the next.

${ }^{6}$ The abbreviated names of these and other stocks will be used throughout the remainder of the report. 
From these last two tables we might conclude, then, that the rootstock $A \times R \# 1$ has shown a wide range of adaptability for the vineyard soils of the coastal counties of California and performs well with several of the commonly grown $V$. vinifera varieties of grapes. An examination of the summarized data in the seventeen vineyard trials certainly confirms this conclusion.

\section{ROOTSTOCK PERFORMANCE}

More than 50 years of investigations with phylloxera-resistant grape rootstocks have preceded the inauguration of the series of cooperative field trials reported in this publication. Much of this previous work was done by pioneer research men in Europe as well as by growers and investigators in California. These early investigations have served as a basis for the choice of the limited number of phylloxera-resistant stocks which were thought to be the most likely to be suitable for California conditions.

It is understood that environmental conditions in the commercial vineyards in which the individual experiments were set up could introduce variability in the data obtained that could not be measured in plots of this nature. This criticism can be brought to bear upon the data gathered from non-replicated field trials of the nature of those in this report.

Intensive research carried on under the most carefully controlled conditions is essential to establish sound recommendations for commercial practices. However, work leading to these fundamental facts must necessarily be conducted at one or a few locations in order to make possible the careful collection of observations and data. There is a possibility of serious criticism if the results of such research are translated into terms of vineyard practices for growers without further tests under commercial field conditions in the regions where they are to be applied. Difficulties of this kind are common when viewed in the light of modern statistical procedures. They point to the need for further cooperation between the theoretical statistician and the viticulturist in designing and analyzing the data gathered on research investigations carried out in the field.

The grape rootstock work currently reported has supplied from 15 to 20 years of observations and data on a large number of widely distributed field trials of grape rootstocks. In the eyes of the mathematician it may appear to be a meager collection of usable data. To the viticulturist however, it represents a rather widespread and thorough test of grape rootstocks.

On the basis of the data gathered from these cooperative field trials, together with a number of years of observations on the general response in growth and production of many scion varieties on a wide array of rootstocks in California vineyards, the following summary statements are made of the rootstocks of greatest interest.

Rupestris St. George (synonym Rupestris du Lot). This rootstock is a pure seedling selection chosen from the wild grape species, Vitis rupestris. St. George is the rootstock used almost exclusively in the table-wine areas of the coastal valleys of California. This stock roots very well from cuttings, is compatible with practically all $V$. vinifera varieties, and exhibits a high degree of phylloxera resistance. It is moderate in vigor and has given satis- 
factory vineyard performance in some of the areas in which it is used. The rootstock's main deficiencies are a tendency to produce straggly clusters and, under some conditions, to set many shot berries. This characteristic is most pronounced with low-yielding varieties, where small reductions in yield could be quite undesirable.

In spite of the low yields on this rootstock throughout the cooperative trials in comparison with other stocks there is still a place for the use of Rupestris St. George in California vineyards. This place is in vineyards of the coastal valleys on shallow, non-irrigated soils, which are usually low in moisture late in the summer. In such shallow soils the phylloxera resistance of St. George may be a prime criterion in its choice as a stock. It also is the rootstock of choice with heavy-producing wine varieties. Longer pruning of the scion variety should be used in order to balance the fruiting of the vines on this stock with the vigor which they display. This will help to compensate for the poor cluster formation that varieties on this stock show. St. George produces rootstock suckers profusely. The cuttings should be thoroughly disbudded prior to rooting in the nursery and the grafted vines should be carefully suckered during the first three or four years in the vineyard.

Riparia Gloire de Montpellier. This rootstock is a seedling selection from representatives of the wild grape species Vitis riparia. Its performance has not been satisfactory in the dry, non-irrigated, and shallow soils frequently found in the coastal valleys of California. It has performed reasonably well in the more fertile, moist soils of a few locations on the valley floors. Vines grafted on it have been low in vigor and yield. In general, this stock has produced vines which have fruit of good quality and early maturity, but currently there appears to be no place for this rootstock in the non-irrigated vineyards of California.

Dogridge. This rootstock is a seedling selection from the grape species Vitis champini. It is regarded as only moderately resistant to phylloxera and has been used in California for its high degree of nematode resistance. In the sandy, irrigated soils of the hot regions of California it has shown extreme vigor, and has been useful in locations with adverse growing conditions where less vigorous stocks have failed. In the non-irrigated, heavier soils of the coastal counties of California the stock has proven to be very inconsistent in growth and fruiting habits. In addition, cuttings of this rootstock root with great difficulty and have been very difficult to handle with the propagation techniques commonly used in California.

Solonis $\times$ Othello 1613 and Solonis $\times$ Riparia 1616. These two hybrid rootstocks are both noted for their combined resistance to phylloxera and plant parasitic nematodes. In sandy irrigated soil of good fertility these stocks have performed remarkably well ; 1613 currently being the most widely used rootstock in the interior valleys of California. Cuttings of these two varieties root with ease and graft readily.

In the trials in the dry, non-irrigated vineyards of the coastal valleys the vines grafted to these stocks have been weak and unproductive. They therefore cannot be recommended for use in the phylloxerated areas of the coastal valleys of California. 
Riparia $\times$ Rupestris 3306 and 3309. These two hybrid rootstocks were produced by crossing selections of $V$.riparia and $V$. rupestris. They are among the oldest of the hybrid rootstocks used today and have been thoroughly tested under a wide array of viticultural situations in the grape-growing areas of the world. Both are quite resistant to phylloxera; their cuttings root with ease and readily graft to $V$. vinifera varieties. These two stocks have performed satisfactorily in California, but neither have been outstanding in the field trials when compared with other stocks. It is only in rare instances that either of these stocks has been a failure. However, in practically all situations their performance, both in yield of fruit and vine vigor, has been surpassed by one or more of the other rootstocks. In general, 3309 has been a more predictable rootstock than 3306 . The vigor of 3309 is slightly greater than that of 3306 and the yields of fruit slightly larger. From the data gathered on these two stocks in these trials and from the numerous observations made upon their performance in California vineyards over the past 50 years, they cannot be recommended for further planting in California.

Berlandieri $\times$ Rupestris 99-R, 110-R, 57-R, and 44-R. These four hybrid stocks were produced by the Richter Nurseries of France by hybridizing varieties of the two wild grape species, V. berlandieri and V. rupestris. They are relatively new rootstocks and each differs only slightly from the other. They are quite resistant to phylloxera, root their cuttings readily, and graft with ease. They display a high tolerance to high limestone soil, which was the primary objective in the production of this series of rootstocks. However, since the vineyard areas of the coastal valleys of California do not have soils sufficiently high in limestone to make it necessary to use rootstocks carrying a high tolerance to lime, this requirement was not considered in the experimental trials.

The rootstock 99-R has consistently ranked among the better stocks in the cooperative field trials, frequently outproducing St. George in the drier, nonirrigated locations. The vines grafted on $99-\mathrm{R}$ do not display great vigor, and the young vines do not develop as rapidly as those on other stocks. On the other hand, as the vines on this stock reach maturity their yield has been very good and the character of the fruit excellent. The rootstock 99-R has proved to be the best of the newer phylloxera-resistant rootstocks and is a very worthy rival for the position held by Rupestris St. George on the shallower, non-irrigated soils of the coastal valleys of California.

The rootstocks $57-\mathrm{R}$ and $110-\mathrm{R}$ have performed well in some situations but both seem to be more sensitive to unfavorable soil conditions. The stock $110-R$ has the fault of producing abnormally large unions with many common fruiting varieties. Where these stocks have been tried neither has been equal to the performance of $99-\mathrm{R}$.

The stock 44-R has not been sufficiently tested in California vineyards to warrant statements regarding its usefulness or its limitations. It appears to perform in a manner quite similar to the stocks 57-R and 110-R under the conditions where it has been tried.

Berlandieri $\times$ Riparia 420-A and 5-A. Neither of these hybrid stocks produced by crossing $V$. berlandieri and $V$. riparia has been extensively tested 
in the phylloxerated areas of California. The high lime-tolerance of these stocks, though very useful in parts of Europe, is of little importance in California.

The older of the two stocks, 420-A, appears to have no place in the shallow, non-irrigated soils found in the table-wine areas of the coastal valleys of the state. In these locations the vines grafted to this stock are inclined to be weak and the crops produced are light. With the exception of its good response with the Cabernet Sauvignon variety in Sonoma County, table 5, it has not been a promising stock.

The stock 5-A is somewhat more vigorous than 420-A. Occasionally it has produced excellent crops of fruit; its performance, however, is erratic in the cooperative trials. It generally was surpassed both in vigor and yield by one or more of the other stocks with which it was being compared.

Neither of these hybrid stocks can be recommended for use in the phylloxerated coastal vineyards of California.

Chasselas $\times$ Berlandieri 41-B. This stock, produced by hybridization of $V$. vinifera and $V$. berlandieri, has been extensively tested in California. Its performance in early tests in this state was strikingly good according to Bioletti, Flossfeder, and Way (1921). Continued trials have not verified the opinions of the earlier investigators. In none of the trials reported in this paper has the stock been outstanding and in some it has done very poorly. (See tables 2 and 12.) Its main faults are the difficulty in rooting of its cutting and the production of weak, slow-growing grafted vines.

Bourrisquou $\times$ Rupestris 93-5. This stock is a hybrid between $V$. vinifera and $V$.rupestris. It is vigorous, easy to root from cuttings, and grafts readily. This stock appears to be somewhat drought resistant and suitable for heavier soils. It is reported to be attacked by phylloxera, but is sufficiently vigorous to remain healthy in the better soils of the coastal valleys of California. Although 93-5 has not been thoroughly tested, in the trial in which it was placed (table 1), it has performed fairly well.

Vinifera $\times$ Rupestris XX. The true name and origin of this stock are unknown. It appears to be a $V$. vinifera $\times V$. rupestris hybrid, having been imported to California as a mixed variety in a shipment of rootstocks from Europe some years ago. It was first planted extensively in the Ukiah area at the upper end of the Russian River Valley in Mendocino County. It has been tried in a number of locations of known phylloxera infestations and its behavior has been questionable. In controlled tests phylloxera has attacked it strongly. Vines grafted upon it have been vigorous and productive. Yet, if the stock is to be used at all, it should only be in areas where the severity of phylloxera attack is limited. It is not recommended for further trials in California.

Mourvèdre $\times$ Rupestris 1202 and Aramon $\times$ Rupestris Ganzin \#1. These two experimental rootstocks are hybrids between varieties of $V$. vinifera and the phylloxera-resistant $V$. rupestris. They are both old, widely tested stocks, are vigorous growers, root their cuttings very easily, and graft readily. The phylloxera resistance of these stocks is not high, as numerous experiments in other viticultural areas of the world have demonstrated. It is understood 
that in very dry, shallow soils and in areas where phylloxera can be serious they may do poorly or even fail. In the extensive trials that they have been subjected to in California, however, they have performed remarkably well.

The stock 1202 is slightly more resistant to phylloxera than $A \times R \# 1$. In the few trials located on the shallower, drier soils it has performed well. (See tables 3,10 , and 13.) It grows as vigorously as Rupestris St. George and has regularly borne heavier crops.

The stock $\mathrm{A} \times \mathrm{R} \# 1$ has been the outstanding experimental stock in these field trials. Its great vigor has been expressed consistently and the yields of the varieties grafted on it have been repeatedly the highest of any of the stocks used. The clusters produced by grafted varieties have been large, loose, and of high quality.

Despite its only moderate phylloxera resistance it has performed remarkably well. From the data obtained in the cooperative trials its appears to be the nearest approach to an all-purpose stock for the coastal counties of California that is available. For both light- and heavy-bearing varieties in the more fertile soils having adequate moisture, that is, on the valley floors of the coastal counties, this stock is at present the best choice.

\section{ACKNOWLEDGMENTS}

The author wishes to express his appreciation to the following growers for their cooperation in maintaining the field trials in their vineyards: L. M. Athenour, P. Hopper, J. Luchessi, L. M. Martini and Son, A. P. Mathews, A. Matteri, Mead Ranch, The Novitiate of Los Gatos, F. Salmina and Sons, San Martin Vineyard Company, W. Sink and Son, J. S. Smoyer, J. N. Stipp, and Wente Brothers. Thanks are also due to the Farm Advisors in whose counties these trials were conducted for their assistance in establishing the trials and gathering data from them over the years. The author also wishes to thank his colleagues in the Department of Viticulture for advice and consultation during the course of this investigation and for suggestions and criticisms in the preparation of this report.

\section{SUMMARY}

The grape phylloxera has spread through most of the commercial grapegrowing areas of the world. During the last 100 years the quest for suitable grape rootstocks resistant to the pest has constituted a large body of intensive research.

Phylloxera was introduced into California prior to the year 1860 and since has spread generally over the state. The extent of infestation and its intensity within any given area are markedly influenced by the soil and climatic conditions existing in the area.

Grape rootstock investigations during the past 50 years by the United States Department of Agriculture and the Department of Viticulture of the College of Agriculture have provided a basis for selecting a limited number of rootstocks for current cooperative field trials.

The cooperative rootstock tests are located in vineyards scattered throughout the coastal valleys-one of the important grape-growing areas of Cali- 
fornia. This series of trials was evolved in order to evaluate the performance of a few chosen experimental rootstocks with a number of fruiting varieties under a wide range of environmental conditions.

The results of early rootstock trials in California, when compared with the results obtained on grafted vines in the commercial vineyards of the state, showed considerable disagreement. In addition, earlier trials conducted by the Department of Viticulture showed a distinct discordance in the behavior of the same stocks at more than one location when the same scion variety was used.

A statistical survey of the data collected has shown that the most popular rootstock used commercially, Rupestris St. George, is not the most suited under the conditions tested, whereas the experimental stock $\mathrm{A} \times \mathrm{R} \# 1$ is generally the most vigorous and productive of the stocks under consideration.

\section{LITERATURE CITED}

\section{ANONYMOUS}

1881. Acts of the Legislature. First Annual Report of the Board of State Viticultural Commissioners, California. Second Ed. (Revised), pp. 5-8.

1949. Code of Federal Regulations, United States (Revised, 1953). Title 7, Part 51, Par. 880-911.

ApPleton, H.

1880. The phylloxera-vastatrix and its ravages in Sonoma Valley. First Annual Report of the Board of State Viticultural Commissioners, California. Second Ed. (Revised). Appendix C, pp. 108-11.

BAZILLE, G.

1871. Etudes sur le phylloxera. Le Messager Agricole du Midi 12: 190-3.

BIOLETTi, F. T., F. C. H. Flossfeder, and A. E. WAY

1921. Phylloxera resistant stocks. California Agr. Exp. Sta. Bul. 331:1-139.

Couderc, G.

1888. Etude sur l'hybridization artificielle de la vigne. Mem. de la Soc. Natl. d'Agr. 132:401-5.

Davidson, W. M., and R. L. Nougaret

1921. The grape phylloxera in California. U. S. Dept. Agr. Bul. 903:1-28.

Fitch, Asa

1854. Report upon the noxious and other insects of the State of New York. N. Y. State Agr. Soc., Trans. Vol. XIV : 862-3.

HARASZThy, A.

1882. Report of Arpad Haraszthy, Commissioner for San Francisco District. Second Annual Report of the Board of State Viticultural Commissioners, California, pp. $46-51$.

Hayne, A. P.

1896. Resistant vines; their selection, adaptation and grafting. Appendix to Viticultural Report. Univ. of Cal., Col. of Agr., pp. 375-9.

HiLGARD, E. W.

1884. The phylloxera at Berkeley. Univ. of Calif., Col. of Agr. Report of the professor in charge to the president. Appendix No. IV, pp. 205-9.

Husmann, G. C.

1910. Grape investigations in the vinifera regions of the United States with reference to resistant stocks, direct producers and viniferas. U. S. Dept. Agr. Bul. 172:1-86.

Husmann, G. C., Elmer SNyder, and F. L. Husmann

1939. Testing vinifera grape varieties grafted on phylloxera-resistant rootstocks in California. U. S. Dept. Agr. Tech. Bul. 697:1-63. 
KRUG, C.

1882. Report of Charles Krug, Commissioner for Napa District. Second Annual Report of the Board of State Viticultural Commissioners, California, pp. 43-5.

Krug, C., H. W. CRABB, and J. H. WheELER

1887. Report of the committee appointed to examine into the uses of mercury for destroying phylloxera. Annual Report of the Board of State Viticultural Commis-

LALILMAN, L. sioners, California, pp. 47-8.

1869. Lettre sur l'immunité de certains cépages Américains dérivant du Vitis aestivalis. Le Messager Agricole du Midi 10: 285.

MAZADE, M.

1894. Etude sur les Rupestris. Revue de Viticulture, 1:238-42.

MillaRdet, A.

1885. Historie des principles varieties, et especes de vignes d'origine Americaine qui resistant an phylloxera. A. Masson, Paris. 240 pages.

Novgaret, R. L., and M. H. LAPHAM

1928. A study of phylloxera infestation in California as related to types of soils. U. S. Dept. Agr. Tech. Bul. 20:1-38.

Planchon, J. E., G. Bazille, and F. Sahut

1868. Sur une maladie de la vigne actuellement règnante en provence. Compt. Rend. $67: 333-6$.

RAVEZ, L.

1895. Les riparias, les rupestris, les berlandieri. Revue de Viticulture $3: 117-9$; 144-6; $369-70$.

SAHUT, F.

1885. Les vignes Americaines, leur greffage et leur taille. Grollier et Fils, Montpellier.

SHIMER, H. 551 pages.

1867. On a new genus (Dactylasphaera) in homoptera. (Section Monomera) Philad. Acad. Nat. Sci. Proc. 10:2-11.

Viala, P.

1889. Une Mission viticole en Amérique. C. Coulet, Montpellier. 387 pages.

VIALA, P., and L. RAVEZ

1896. Les vignes Américaines: Adaptation, culture, greffage, pepinieres. 2nd Ed. Firmin-Didot et Cie. 390 pages. 


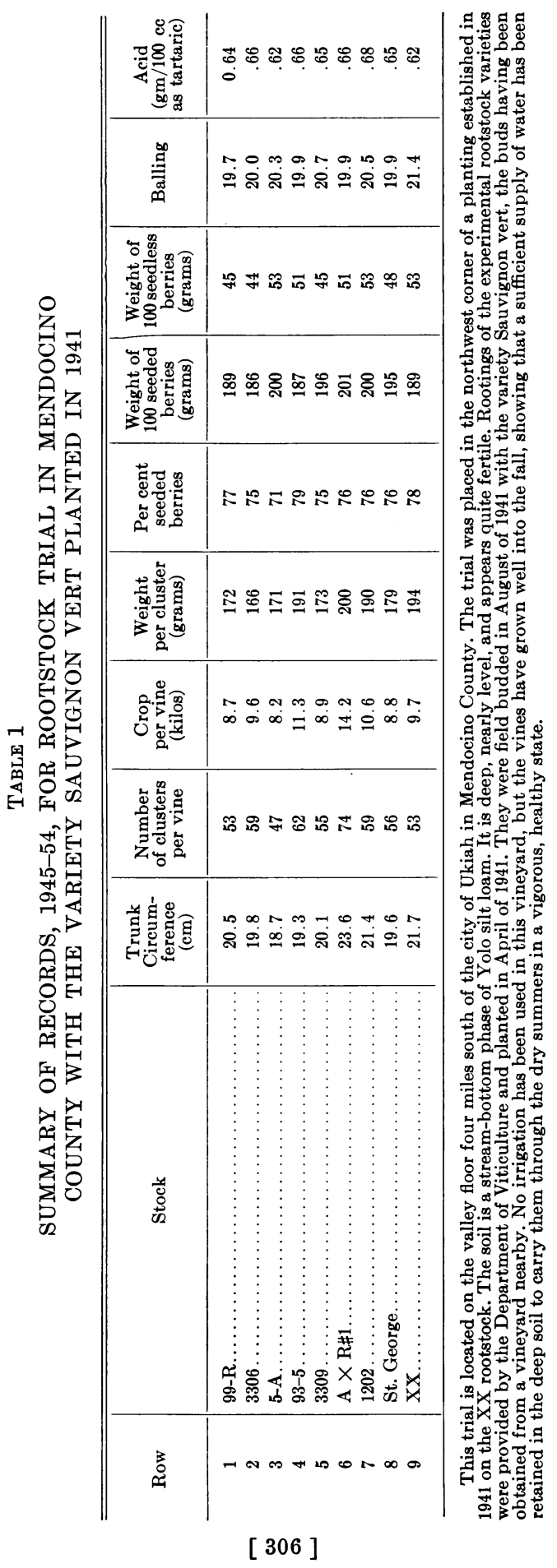




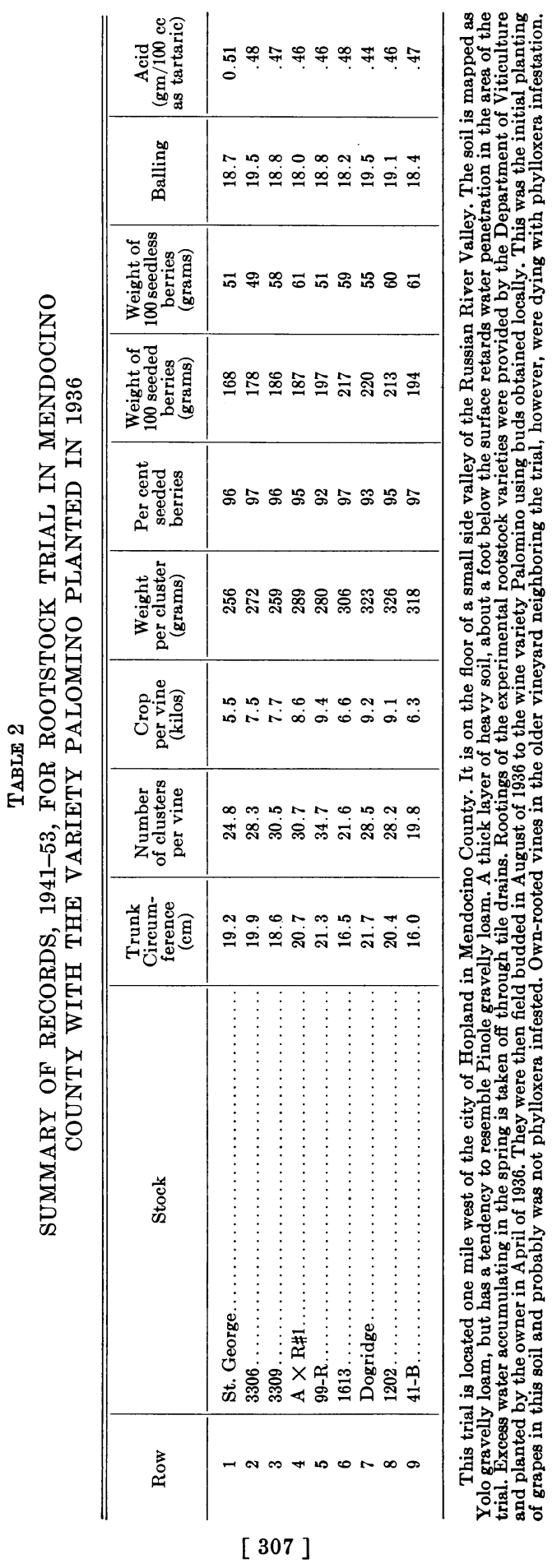




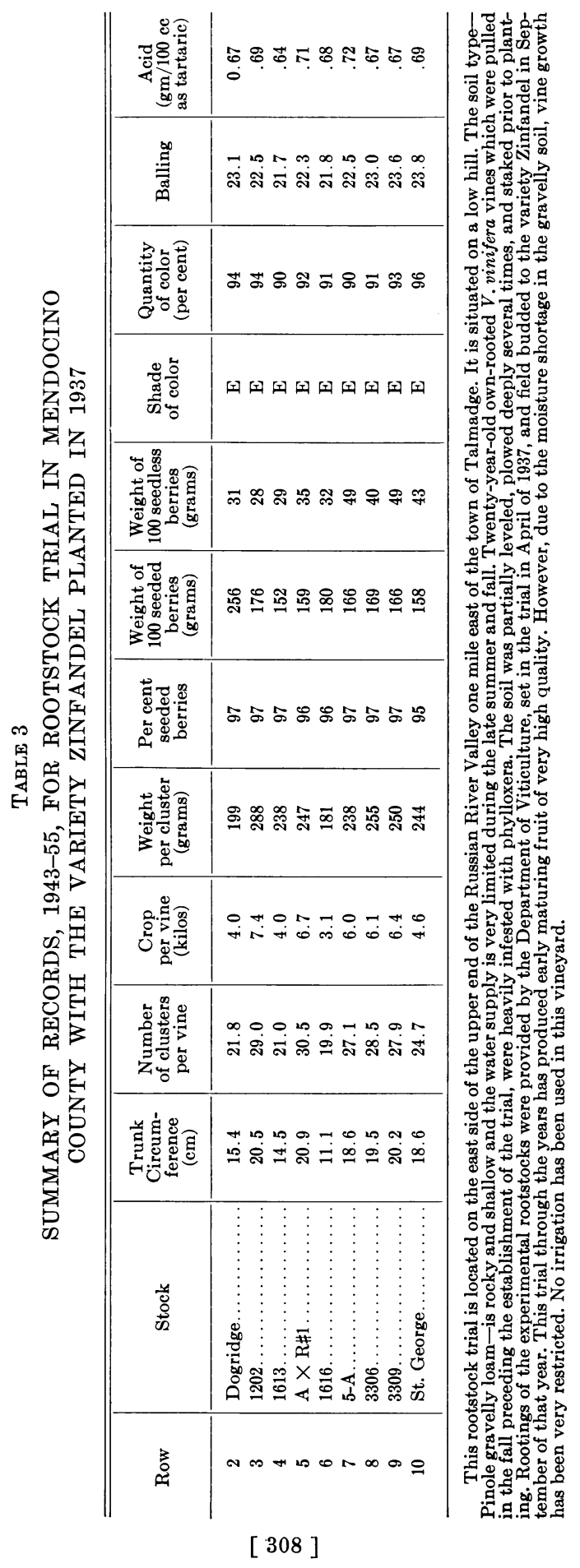




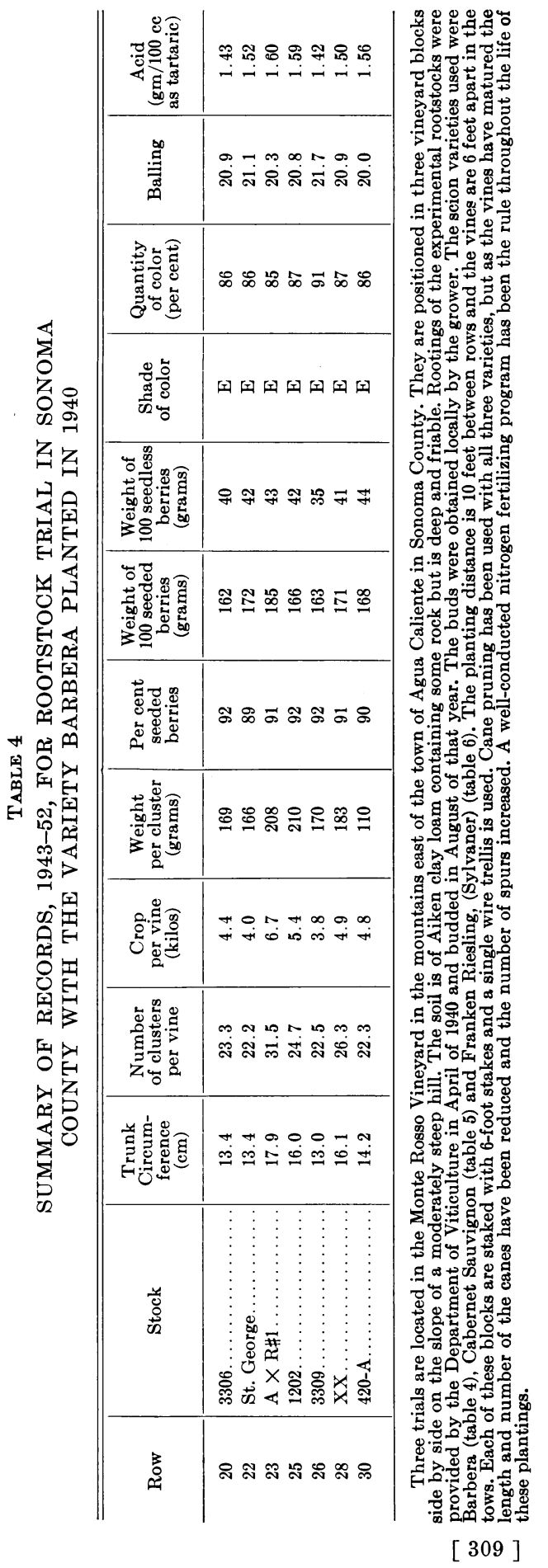

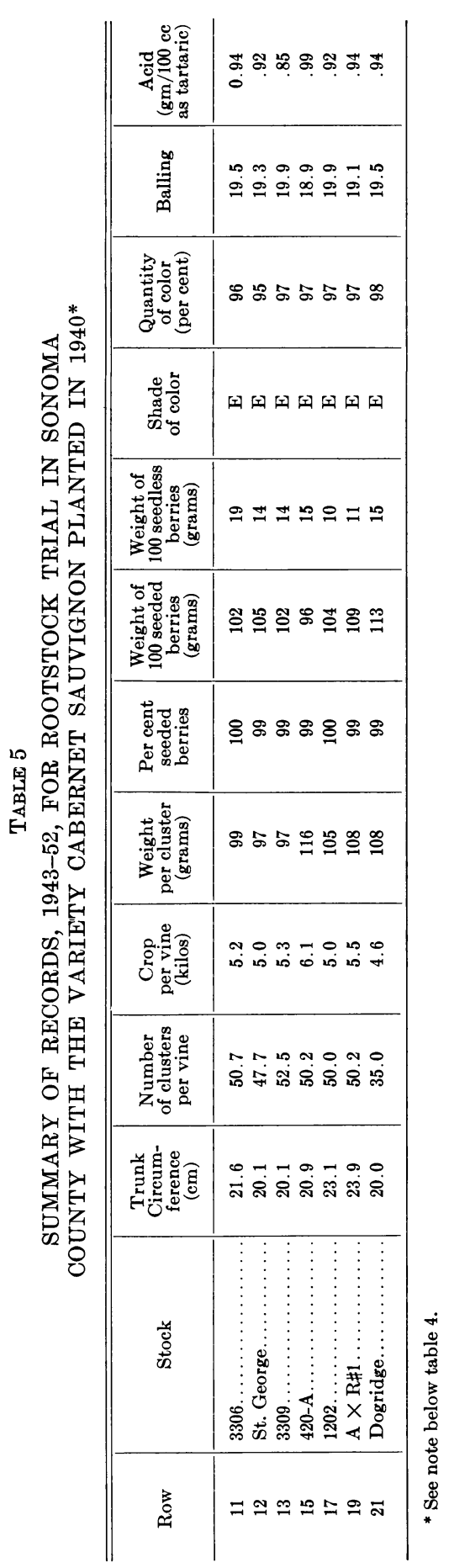



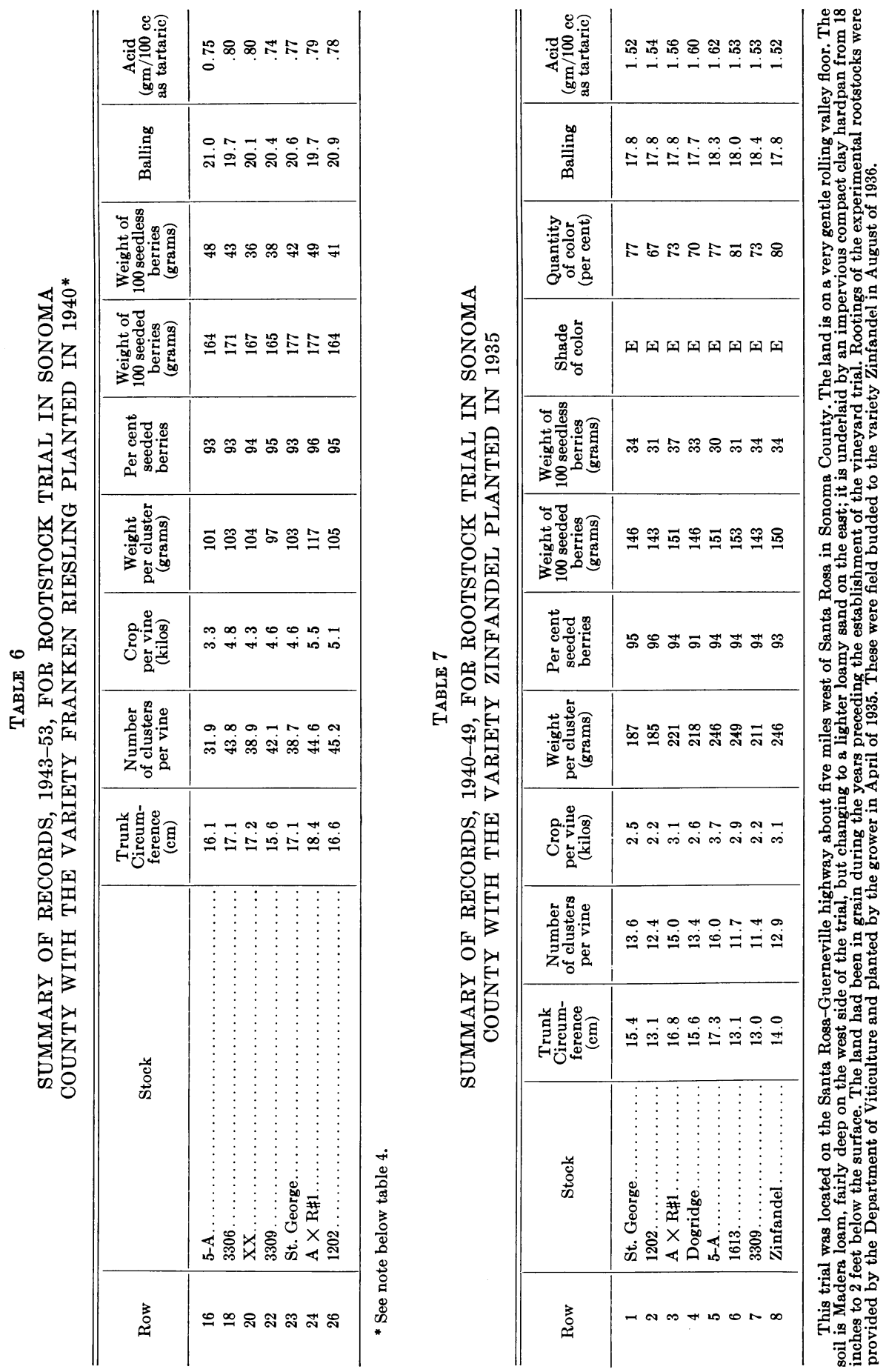


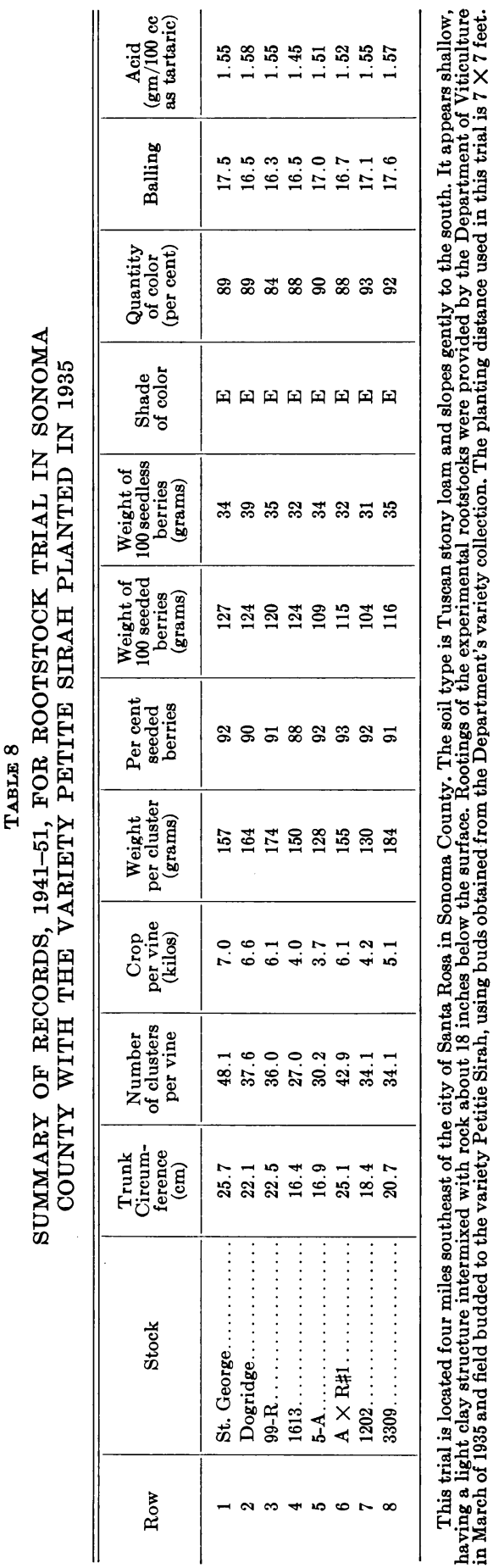

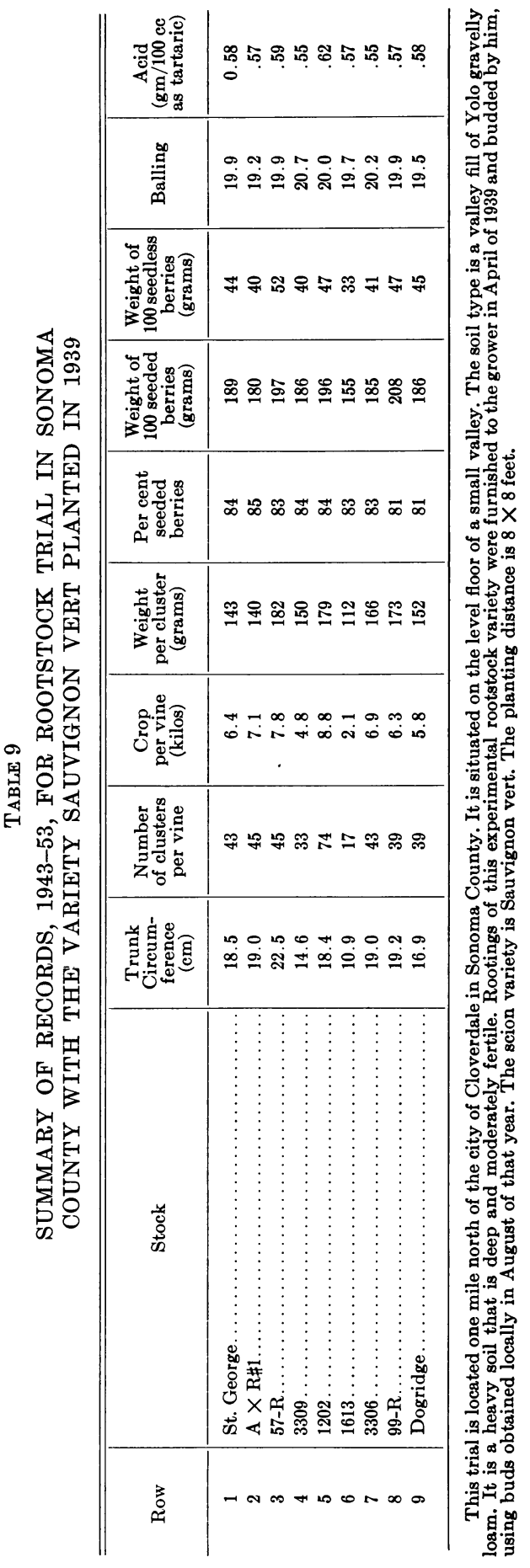




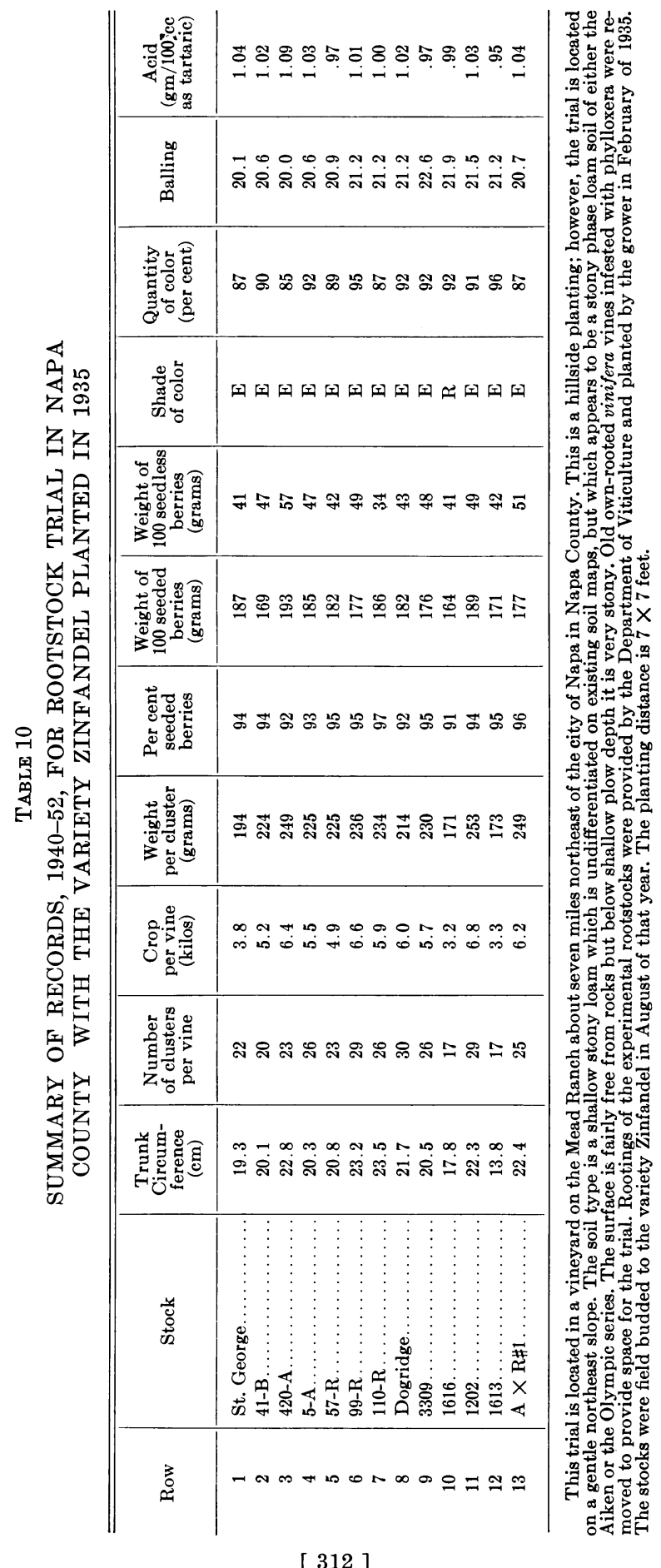

[ 312 ] 


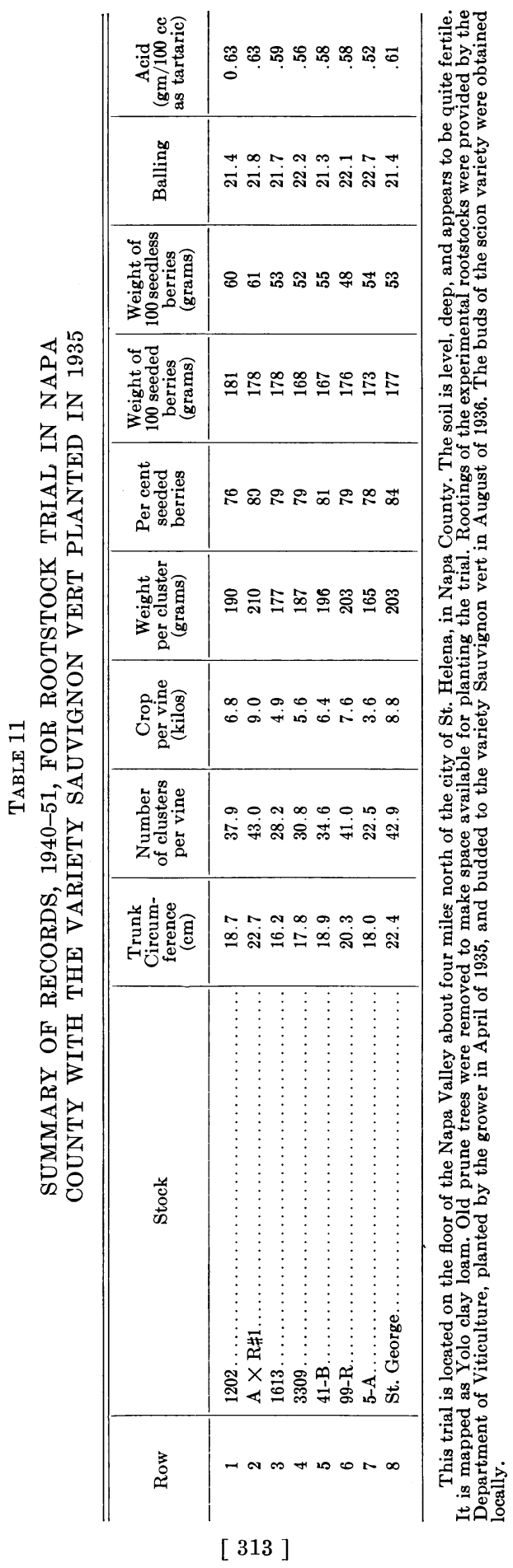



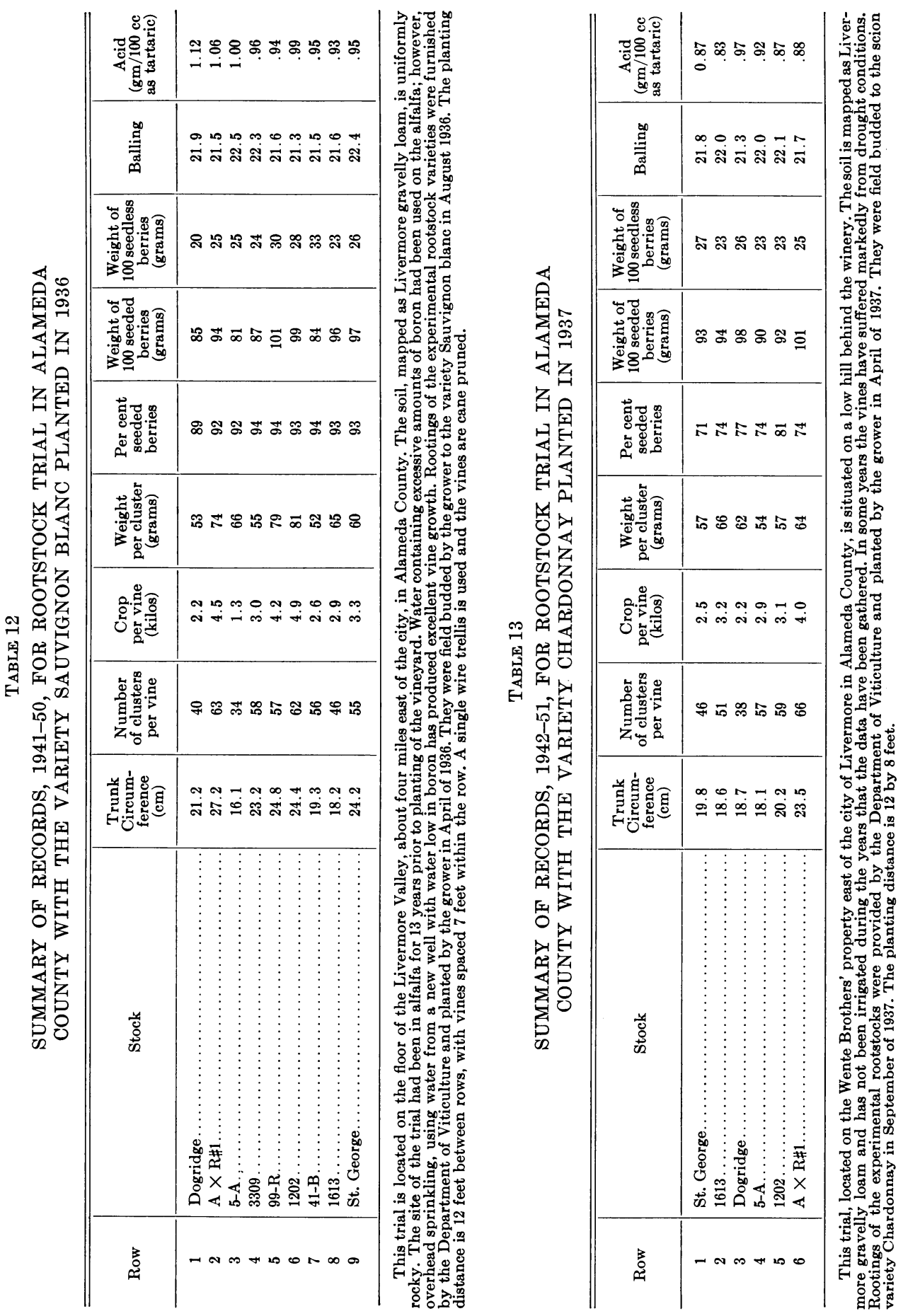

[ 314 ] 

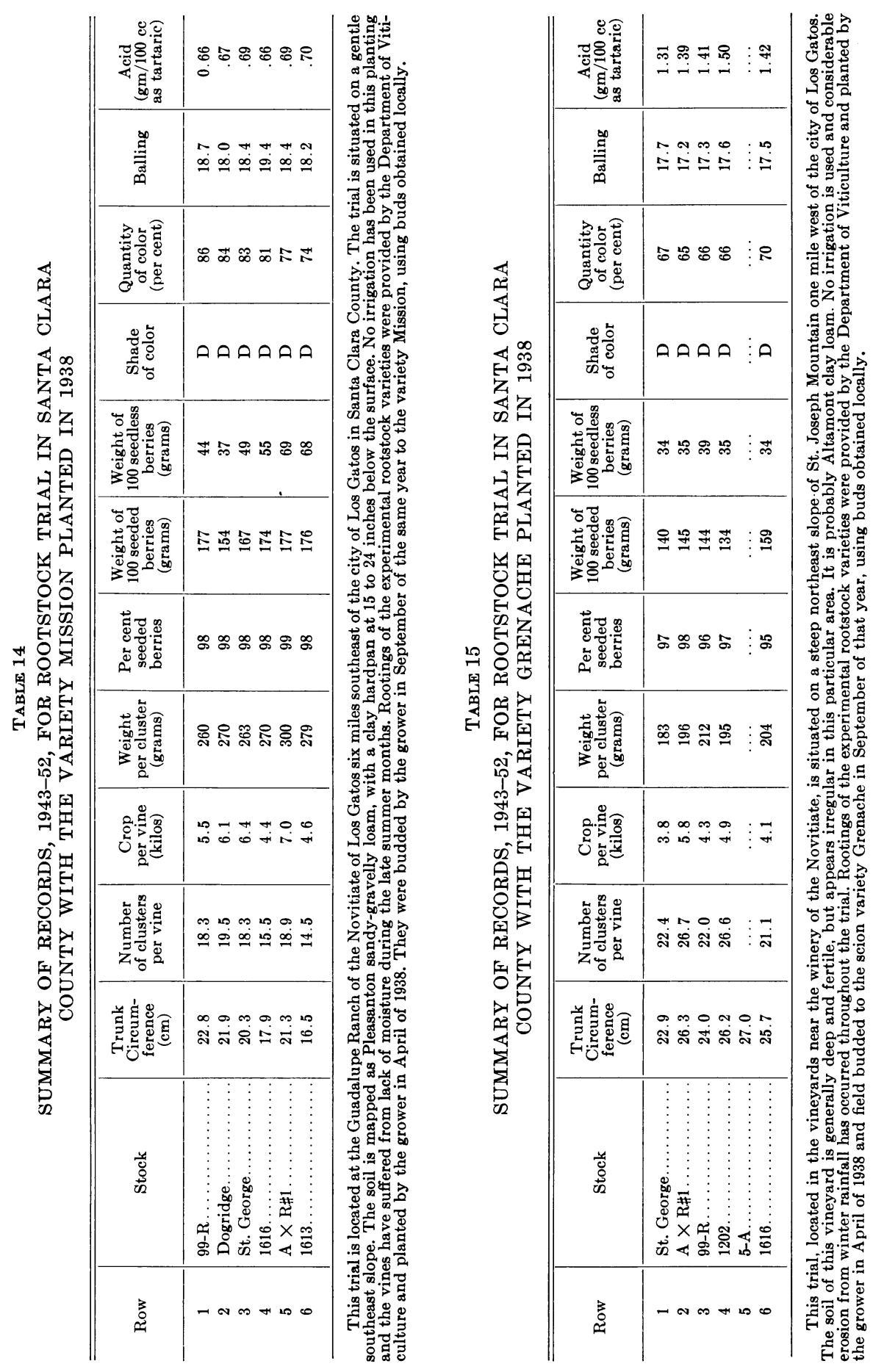


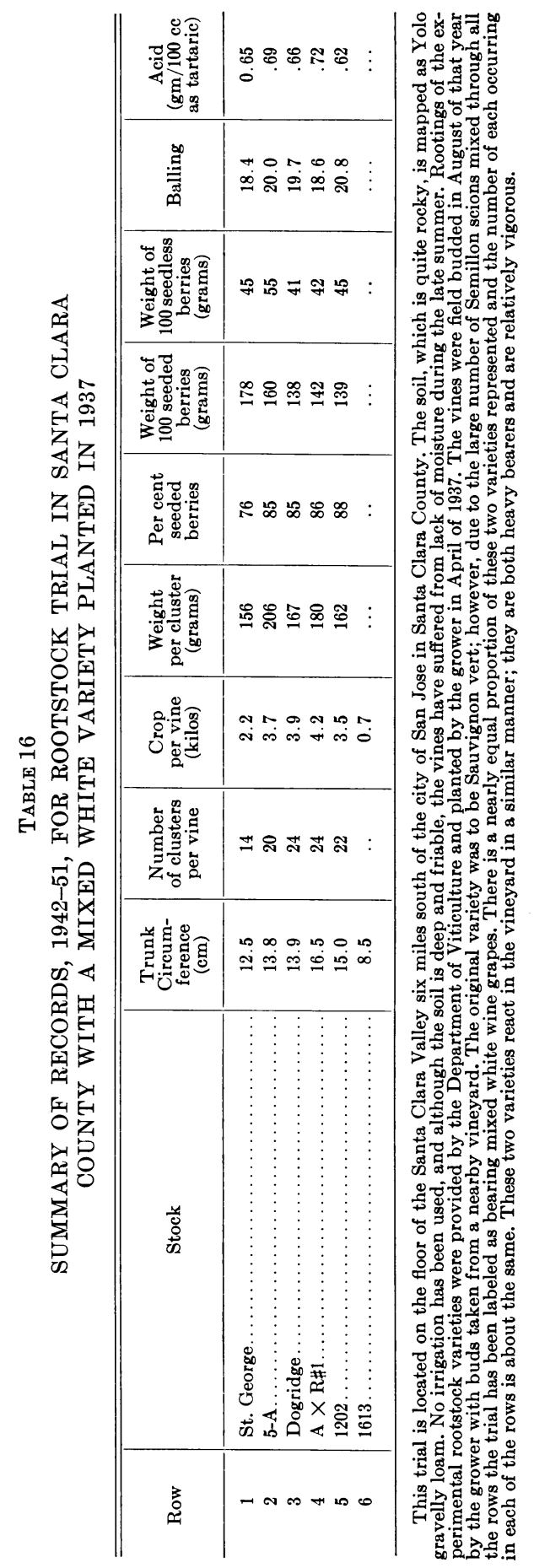

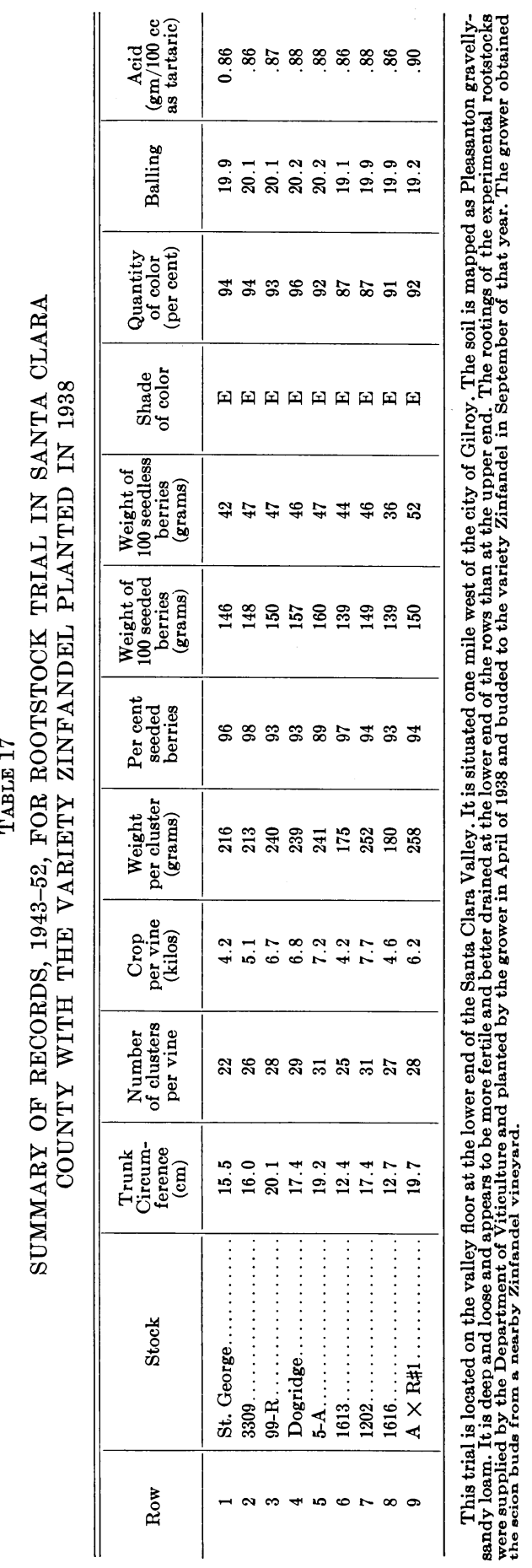

[ 316 ] 
TABLE 18

TEN-YEAR AVERAGES OF CROP WEIGHT PER VINE (KILOGRAMS) IN NINE TRIALS OF FOUR ROOTSTOCKS

\begin{tabular}{|c|c|c|c|c|}
\hline Sauvignon blanc................. & 3.3 & 4.5 & 4.9 & 4.2 \\
\hline Sauvignon vert $\ldots \ldots \ldots \ldots \ldots \ldots \ldots \ldots$ & 8.8 & 14.2 & 10.6 & 8.7 \\
\hline Zinfandel......... & 3.8 & 6.2 & 6.8 & 6.6 \\
\hline Mission................... & 6.4 & 7.0 & 7.0 & 5.5 \\
\hline Sauvignon vert. . . & 6.4 & 7.1 & 8.8 & 6.2 \\
\hline Petite Sirah...... & 7.0 & 6.1 & 4.2 & 6.1 \\
\hline Total $\ldots \ldots \ldots \ldots \ldots \ldots \ldots \ldots \ldots$ & 49.2 & 65.7 & 64.0 & 57.7 \\
\hline
\end{tabular}

Standard Error of totals at $5 \%$ level $=10.8$

at $1 \%$ level $=14.7$

TABLE 19

TEN-YEAR AVERAGES OF TRUNK CIRCUMFERENCES (CENTIMETERS) IN NINE TRIALS OF FOUR ROOTSTOCKS

\begin{tabular}{|c|c|c|c|c|}
\hline Vine variety & St. George & $A \times R \# 1$ & 1202 & $99-\mathrm{R}$ \\
\hline Sauvignon blanc................... & 24.2 & 27.2 & 24.4 & 24.8 \\
\hline Sauvignon vert $\ldots \ldots \ldots \ldots \ldots \ldots \ldots \ldots$ & 19.6 & 23.6 & 21.4 & 20.5 \\
\hline Zinfandel $\ldots \ldots \ldots \ldots \ldots \ldots \ldots \ldots \ldots$ & 19.3 & 22.4 & 22.3 & 23.2 \\
\hline Mission $\ldots \ldots \ldots \ldots \ldots \ldots \ldots \ldots$ & 20.3 & 21.3 & 20.7 & 22.8 \\
\hline Sauvignon vert $\ldots \ldots \ldots \ldots \ldots \ldots \ldots$ & 18.5 & 19.0 & 18.4 & 19.2 \\
\hline Petite Sirah $\ldots \ldots \ldots \ldots \ldots \ldots \ldots \ldots \ldots$ & 25.7 & 25.1 & 18.4 & 22.5 \\
\hline Total....... & 185.2 & 205.3 & 189.6 & 198.4 \\
\hline
\end{tabular}

Standard Error of totals at $5 \%$ level $=13.9$ at $1 \%$ level $=18.8$

TABLE 20

TEN-YEAR AVERAGES OF CROP WEIGHT PER VINE (KILOGRAMS) FOR THE VARIETY ZINFANDEL AT FOUR LOCATIONS ON FOUR ROOTSTOCKS

\begin{tabular}{|c|c|c|c|c|}
\hline County & St. George & $A \times R \# 1$ & 1202 & 3309 \\
\hline Mendocino........... & 4.3 & 6.6 & 6.7 & 6.3 \\
\hline Napa $\ldots . . . \ldots$. & 3.8 & 6.2 & 6.8 & 5.7 \\
\hline Santa Clara . . . . . & 4.2 & 6.2 & 7.7 & 5.1 \\
\hline 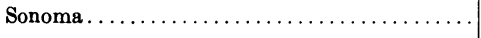 & 2.5 & 3.1 & 2.2 & 2.2 \\
\hline
\end{tabular}

Standard Error of totals at $5 \%$ level $=\mathbf{5 . 4}$ at $1 \%$ level $=7.7$ 
TABLE 21

TEN-YEAR AVERAGES OF CROP WEIGHT PER VINE (KILOGRAMS) FOR THREE VARIETIES IN ONE VINEYARD IN SONOMA COUNTY ON FIVE ROOTSTOCKS

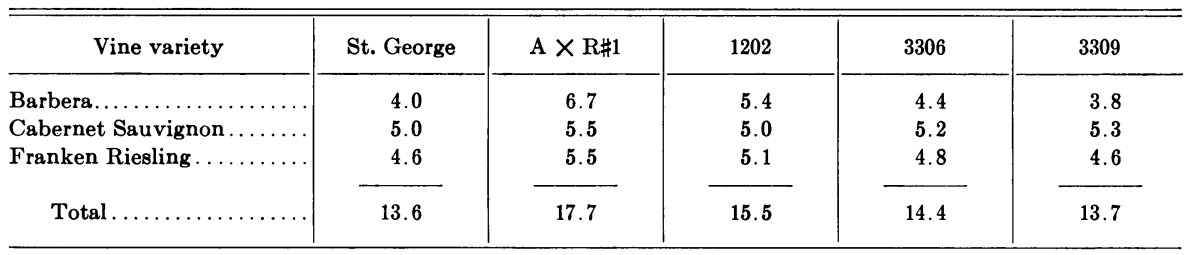

Standard Error of totals at $5 \%$ level $=4.0$ at $1 \%$ level $=5.8$ 
The journal Hilgardia is published at irregular intervals, in volumes of about 600 pages. The number of issues per volume varies.

Subscriptions are not sold. The periodical is sent as published only to libraries, or to institutions in foreign countries having pub. lications to offer in exchange.

You may obtain a single copy of any issue free, as long as the supply lasts; please request by volume and issue number from:
Agricultural Publications
Room 22, Giannini Hall
University of California
Berkeley 4, California

The limit to nonresidents of California is 10 separate issues on a single order. A list of the issues still available will be sent on request. 


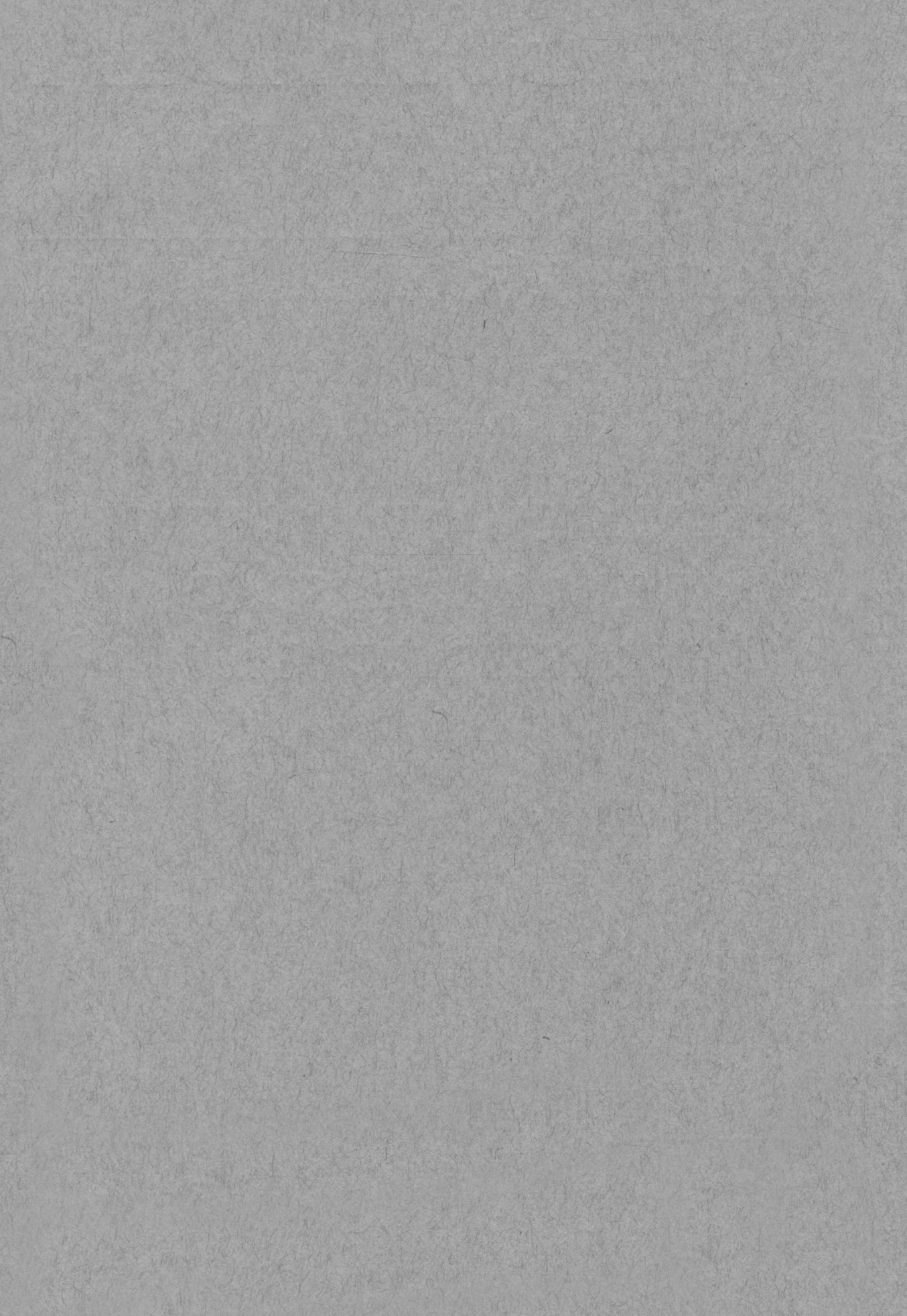

